\title{
Antibacterial Activities of Extract Curly Chili (Capsicumannum. L) on Fusobacterium Nucleatum: An in Vitro Study
}

\author{
Sisca Yudistira \\ Baiturrahmah University, Padang \\ siscay22@yahoo.com
}

\author{
Widyawati, Resti Iswani \\ Departement of Conservative \\ Baiturrahmah University, Padang, \\ widyaramuna@yahoo.co.id,restyiswani@gmail.com
}

\begin{abstract}
The progress of most caries process caused the root canal infection. Bacteria that dominated in root canal infection were Fusobacterium nucleatum bacteria that were $48 \%$. This infection needed endodontic treatment. One of the influencing factors was microorganism. It can be eradicated by root canal irrigation. The common substance used for root canal irrigation was Chlorhexidine $2 \%$. However, there are many researches done nowadays to find the alternative substances that are originated from nature. Curly chili is one of the alternatives that can be chosen as root canal irrigation material because it contains the substance useful as antibacterial that is capsaicin. The purpose of this research was to know the effect of Curly chili extract (Capsicum annuum, $L$ ) to the development of Fusobacterium nucleatum bacteria. It was the laboratory experimental research. Statistical analysis used KruskallWallis test. The result of the research showed that the highest barrier zone diameter average at $100 \%$ concentration was $23.50 \mathrm{~mm}$ and control $(+) 24.50 \mathrm{~mm}$ with $p=0.000(<0.05)$. Based on the research, it can be concluded that there was antibacterial activity of Curly chili (Capsicum annuum, L) in concentration of $20 \%$, $40 \%, 60 \%, 80 \%, 100 \%$ and control $(+)$ to pursue the growth of Fusobacterium nucleatum bacteria. Higher concentration of Curly chili extract (Capsicum annuum, L) was stronger barrier for the growth of Fusobacterium nucleatum bacteria.
\end{abstract}

Keywords-Fusobacterium nucleatum, Capsicum annuum, L, inhibition zone

\section{INTRODUCTION}

Continued caries almost lead to root canal infection [1]. Dominant bacteria are Fusobacterium nucleatum about $48 \%$ [2]. Endodontic treatment, is to eliminate root canal microorganism one of them is with root canal irrigation that must be contained antimicrobial effect [3]. The ideal antimicrobial administered based on sensitivity test is a must that shown the effectiveness against microorganism that cause infection [4].

Alternative medicines from nature are effective against polymicrobial infection [5]. Bioactive substance has more minimal side effect than synthesis substance so that more safety to administered [6]. One of nature's substances that have pharmacology effects is curly chili extract [7].
Research conducted by Zoefri (2015) verified that $100 \%$ curly chili extract has inhibitory zone about 16.05 $\mathrm{mm}$ against carious bacteria Streptococcus mutans [8]. Related to curly chili extract potency as antibacterial agent then conducted antibacterial activity test against Fusobacterium nucleatum in vitro study.

\section{MATERIALS AND METHODS}

\section{A. Plant materials}

Curly chili was taken from chili farm in Bukittinggi. To ensure that is curly chili (Capsicum annuum. L) then identified at Herbarium Laboratory, Andalas University, Padang. Curly chili dried with oven at $60^{\circ} \mathrm{C}$ and blended to become chili powder.

\section{B. Extraction}

Curly chili powder (Capsicum annuum. L) was soaked with ethanol $96 \%$ for $24 \mathrm{~h}$ in room temperature. After 24h immersion Curly chili extract was filtered till its grout distinct. Macerate would be evaporated with vacuum rotary evaporator at $60^{\circ} \mathrm{C}$ till obtained condensed extract. Extract diluted become concentration $20 \%, 40 \%, 60 \%, 80 \%$ and $100 \%$.

\section{Bacteria}

This research was used amount of Fusobacterium nucleatum obtained from Health Laboratory Office, Yogyakarta.

\section{Media}

Media that used in this research is Mueller Hinton Agar. Bacteria inoculation obtained from bacteria suspension in reaction tube with physiological solution $(\mathrm{NaCl} 0.9 \%)$ then stirred with vortex till $0.5 \mathrm{Mac}$ Farland standards.

\section{E. Assay method}

Antibacterial activity testing with agar diffusion method with well used curly chili extract (Capsicum annuum, L), Chlorhexidine $2 \%$ as positive control and distilled water as negative control. The experiment microbe suspension placed equally in Mueller Hinton Agar. Mueller Hinton Agar media formed well used perforator. In Mueller Hinton Agar well dropped curly 
chili extract (Capsicum annuum, L) with concentration $20 \%, 40 \%, 60 \%, 80 \%, 100 \%$, positive control and negative control amount $25 \mu \mathrm{l}$. Incubation for $24 \mathrm{~h}$ at $37^{\circ}$ C. After $24 \mathrm{~h}$, observe inhibitory zone, to determine size of inhibitory zone by inhibitory zone measurement defined as clear zone in Mueller Hinton Agar surfaces around well.

\section{RESULTS}

Results of antibacterial activity of curly chili extract (Capsicum annum. L) against Fusobacterium nucleatum growth in vitro presented in following Table.

TABLE I. GROWTH OF FUSOBACTERIUM NUCLEATUM INHIBITORY ZONE DIAMETER

\begin{tabular}{|c|c|c|c|c|c|c|c|}
\hline \multirow{2}{*}{ Replication } & \multicolumn{5}{|c|}{ Inhibitory zone (mm) } & control & control \\
\cline { 2 - 6 } & $\mathbf{2 0 \%}$ & $\mathbf{4 0 \%}$ & $\mathbf{6 0 \%}$ & $\mathbf{8 0 \%}$ & $\mathbf{1 0 0 \%}$ & $(+)$ & $(-)$ \\
\hline I & 13.00 & 15.00 & 17.00 & 20.00 & 24.00 & 25.00 & 0,00 \\
\hline II & 12.00 & 15.00 & 16.00 & 22.00 & 23.00 & 24.00 & 0,00 \\
\hline III & 12.00 & 16.00 & 17.00 & 22.00 & 24.00 & 25.00 & 0,00 \\
\hline IV & 12.00 & 15.00 & 17.00 & 22.00 & 23.00 & 24.00 & 0,00 \\
\hline Mean & 12.25 & 15.25 & 16.75 & 21.50 & 23.50 & 24.50 & 0,00 \\
\hline
\end{tabular}

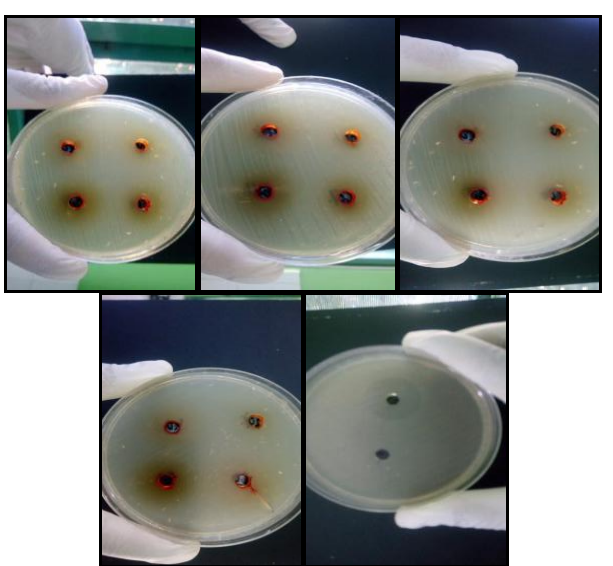

Figure 1. Inhibitory zone of curly chili extract against Fusobacterium nucleatum.

\section{DISCUSSION}

According to Davis and Stout (1971) in Nahak (2012) strength of inhibit to bacteria categorized as follows: very strong (clear zone $>20 \mathrm{~mm}$ ), strong (clear zone $10-20 \mathrm{~mm}$ ), moderate (clear zone $5-10 \mathrm{~mm}$ ), weak $(<5 \mathrm{~mm})$ [9]. Based on that classification antibacterial strength of curly chili extract against Fusobacterium nucleatum at concentration $20 \%, 40 \%$ and $60 \%$ were strong, $80 \%, 100 \%$ and positive control were very strong and negative control was weak.

Result of this study was the higher concentration of curly chili extract then greater inhibitory zone against Fusobacterium nucleatum growth. Similar with Zoefri (2015) verified that the higher concentration of curly chili (Capsicum annuum, L) then more effective against Streptococcus mutans growth. The smallest inhibitory zone in Zoefri (2015) concentration $20 \%$ was $7.01 \mathrm{~mm}$ and continue to increase as concentration increased till the largest inhibitory zone in $100 \%$ was $16.05 \mathrm{~mm}$ [8].

Curly chili antibacterial effect caused by capsaicin is plays a role to interfere bacteria cell membrane synthesis [10]. Disrupted cell membrane synthesis will lead to membrane cell damage so that content of cytoplasm discharge that amount of important component in the bacteria cell such as protein, nucleic acid, and others [11]. This situation would give effect that bacteria are not consisting then finally death [12].

Chlorhexidine 2\% compared to curly chili extract was similar to inhibit growth process of Fusobacterium nucleatum. Differences of inhibitory zone diameter mean between Chlorhexidine 2\% and curly chili extract in concentration $100 \%$ was a $1.00 \mathrm{~mm}$. Statistical analysis verified that there is not significant differences between Chlorhexidine $2 \%$ and curly chili extract in concentration $100 \%$ against Fusobacterium nucleatum. That fact shown that substances in curly chili extract be able to inhibit growth of Fusobacterium nucleatum that as strong as with Chlorhexidine $2 \%$.

According to result can be concluded the highest inhibitory zone in $100 \%$ was $23.50 \mathrm{~mm}$. KruskallWallis $\mathrm{p}=0.000 \quad(\mathrm{p}<0.05)$ there is significant differences antibacterial activity curly chili extract (Capsicum annuum, L) at 20\%, 40\%, 60\%, 80\%, 100\% and positive control against Fusobacterium nucleatum. The higher concentrations of curly chili extract mean to more effective against growth of Fusobacterium nucleatum.

\section{ACKNOWLEDGEMENT}

The authors are gratefully thanking The Herbarium Andalas University for the assistance in taxonomic identification and Health Laboratory Office, Yogyakarta.

\section{REFERENCES}

[1] E. Mulyawati, "Peran bahan disinfeksi pada perawatan saluran akar," Maj. Ked. Gigi, vol. 18(2), 2011.

[2] J.I. Ingle, L.K. Bakland, J.C. Baumgartner, Ingle's endodontics 6, India: BC Decker Inc, 2008.

[3] Widyawati, Dasar-dasar perawatan endodontik II. Padang: Universitas Baiturrahmah, 2010.

[4] K.I. Grossman, S. Oliet, S, R.C. Del, Ilmu endodontik dalam praktek. ed. 11. Terjemahan oleh Abyono R. In: Suryo S, editor. Jakarta: EGC, 2012.

[5] J. Posangi, Juliantri, R. Bara, J. Tairas, J, J. Wuisan, "Uji efek antibakteri tinta cumi-cumi (Loligo sp.) terhadap bakteri saluran akar gigi," e-GIGI, vol, 1(2), 2013.

[6] G.A.S. Smiline, P.J. Vijayshree, S.K. Pandi, P. Hariprasad, R. Raghuraman, "Antibacterial effect of squid ink on ESBL producing strains of Escherichia coli and Klebsiella pneumonia,” Indian J. Mar. Sci., vol. 41(4), 2012.

[7] P. Utami, Buku pintar tanaman obat, Jakarta: PT Agromedia Pustaka, 2008.

[8] U.N. Zoefri, Efektivitas ekstrak cabai keriting (Capsicum annuum, L) berpengaruh terhadap pertumbuhan bakteri Streptococcus mutans secara in vitro, Skripsi, Padang: FKG Baiturrahmah, 2015.

[9] M.M. Nahak, Ekstrak etanol daun beluntas (Pluchea indica. L) dapat menghambat pertumbuhan bakteri Streptococcus mutans, Tesis, Denpasar: Universitas Udayana, 2012.

[10] M.M. Cowan, Plant products as microbial agents," Clinical Microbial Review, vol 12(4), 1999.

[11] R. Setiabudy, H.H.S. Gan, Farmakologi dan terapi, Ed. 4, Jakarta: Badan Penerbit FKUI, 1995.

[12] R. Nursanty, Zumaidar, Potensi antibakteri beberapa tumbuhan obat tradisional, Jurusan Biologi FMIPA Unsyiah DarussalamBanda Aceh, 2013. 